\title{
PENGARUH INSTALASI DRAIN HOLE TERHADAP PENURUNAN MUKA AIRTANAH PADA MEDIA PERMEABILITAS YANG BERBEDA (STUDI KASUS MODEL KONSEPTUAL)
}

\section{Conceptual Model of Groundwater Depressurization in Different Permeability Caused by Drain Hole Instalation}

\author{
Tedy Agung CAHYADI ${ }^{1}$, Lilik Eko WIDODO ${ }^{2}$, Zuher SYIHAB ${ }^{3)}$, \\ Sudarto NOTOSISWOYO ${ }^{2)}$
}

\footnotetext{
1)a Mahasiswa Pasca Sarjana Program Rekayasa Pertambangan ITB

2) Staf Pengajar Program Rekayasa Pertambangan ITB

3) Staf Pengajar Program Teknik Perminyakan ITB

aCorresponding author: tedyagungc.students.itb@gmail.com
}

\begin{abstract}
ABSTRAK Kondisi goegrafis Indonesia yang dilewati garis khatulistiwa mengakibatkan adanya 2 musim, yaitu musim penghujan dan musim kemarau. Tingginya curah hujan yang ada di Indonesia merupakan salah faktor kendala dalam kegiatan penambangan, baik itu Tambang Terbuka maupun Tambang Bawah Tanah. Aliran airtanah pada media porous cenderung memiliki persebaran head yang relatif datar, sedangkan pada media terkekarkan memiliki distribusi persebaran head yang relative bervariasi. Distribusi persebaran paramater akuifer pada media terkekarkan di dalam batuan cenderung heterogen. Instalasi drain hole pada tambang terbuka memiliki tujuan untuk menurunkan muka airtanah (drawdown) agar kestabilan lereng terjaga. Penempatan titik drain hole pada lokasi yang tepat yaitu permeabilitas batuan yang besar mempercepat penurunan muka airtanah dibandingkan dengan penempatan pada permeabilitas yang kecil. Simulasi penempatan drain hole dengan jumlah dan panjang terbatas pada titik yang tepat dapat meningkatkan penurunan muka airtanah secara signifikan dibandingkan dengan instalasi drain hole secara seragam. Implimentasi ini dapat dimanfaatkan untuk rencana penentuan drain hole pada kegiatan penambangan terbuka.
\end{abstract}

Kata kunci: simulasi, drain hole, drawdown, permeabilitas.
ABSTRACT Indonesia is passed equator line causing two seasons, rainy and dry. The high intensity of rainfall in Indonesia is one of limiting factors in mining operation, both Open Pit and Underground Mine. Groundwater flow in porous media tend to have a relatively flat head distribution, while in fractured media head distribution has a relatively varied. In the fractured media, distribution of aquifer parameters in rocks tend to be heterogeneous. Drain holes installation on the open pit has a goal to groundwater depressurization, so the slope stability is well maintained. The right location of drain hole placement is better on high permeability rock than low permeability, because it will accelerate groundwater depressurization. The simulation of drain hole placement with right number and length on the right point will decrease groundwater table significantly, rather than installed uniformly. This implementation can be used to plan the determination of drain hole in the open pit mining activities.

Keywords: simulation, drain hole, drawdown, permeability 


\section{PENDAHULUAN (INTRODUCTION)}

Kegiatan penirisan tambang merupakan salah satu aspek pendukung dalam kegiatan penambangan. Kegiatan tersebut menjadi prioritas apabila kondisi kegiatan penambangan memiliki permasalahan dalam pengelolaan air baik itu air permukaan (run off) maupun airtanah. Munculnya air di lokasi front penambangan dapat mengakibatkan permasalahan seperti produksi penambangan terganggu akibat manuver peralatan yang tidak optimal, longsornya lereng penambangan akibat meningkatnya tinggi muka airtanah sehingga yang berpengaruh terhadap beban gaya penggerak pada lereng. Untuk mengatasi permasalahan airtanah pada lereng dilakukan sistem penirisan tambang. Penurunan muka airtanah di sepanjang lereng biasanya menggunakan sistem pumping well dan atau drain hole. Masing - masing metode tersebut memiliki fungsi tersendiri. Metode pumping well dipasang di sepanjang lereng dengan tujuan menurunkan muka airtanah dengan mengoperasikan pompa dengan periode waktu tertentu. Drain hole adalah metode penirisan dengan membuat pemboran secara horisontal maupun vertikal dengan memanfaatkan gaya gravitasi dalam mengalirkan airnya.

Penanganan airtanah memiliki permasalahan yang cukup rumit dalam kasus batuan yang terkekarkan dengan kondisi geologi yang cukup komplek. Pemasangan drain hole yang terjadi di lapangan sering dijumpai pada kondisi yang seragam, misalnya di sepanjang lereng dengan spasi 10 m. Silaen dkk., 2011 melakukan pemasangan drain hole untuk menurunkan muka airtanah di sepanjang lereng Tambang Terbuka Grasberg. Selain itu, Leech dkk., 2007 juga mengaplikasikan drain hole untuk menurunkan muka airtanah pada media terkekarkan dengan jumlah yang seragam di Tambang Batu Hijau. Instalasi drain hole yang seragam pada media terkekarkan mengakibatkan banyak lubang drain hole yang tidak mengeluarkan airtanah sehingga tidak berfungsi dalam menurunkan muka airtanah. Kondisi ini menyebabkan pemborosan biaya operasional dalam kegiatan penirisan air tambang. Rahardjo dkk., 2003 menyatakan bahwa sedikit jumlah drain hole yang dipasang pada lokasi yang tepat sesuai dengan model konseptual akan lebih efektif daripada jumlah drain hole yang banyak dipasang pada jarak seragam di lereng. Dengan melakukan suatu simulasi dengan simulator Visual Modflow pada studi kasus model konseptual dapat memberikan pemahaman bahwa penempatan lubang drain hole dengan jumlah dan panjang terbatas pada lokasi yang tepat dapat meningkatkan jumlah penurunan muka airtanah yang lebih baik daripada drain hole dipasang pada kondisi seragam.

\section{METODE (METHODS)}

Dalam melakukan simulasi percobaan penempatan drain hole ini akan digunakan suatu model konseptual yang menggambarkan kondisi parameter akuifer secara heterogen. Penyelesaian numerik aliran airtanah menggunakan persamaan finite difference method (FDM) dengan menggunakan perangkat simulator Visual Modflow 2.8.1 (McDonald dkk., 1988). Semua data yang dipakai di dalam model ini adalah asumsi. Tujuan model konseptual ini adalah uji coba dalam rangka membuat percontohan (prototype) model untuk melihat pengaruh distribusi penurunan muka airtanah pada penampatan drain hole dengan skema tertentu. Diagram alir penyelesaian masalah dalam penempatan drain hole dapat dilihat pada Gambar 1.

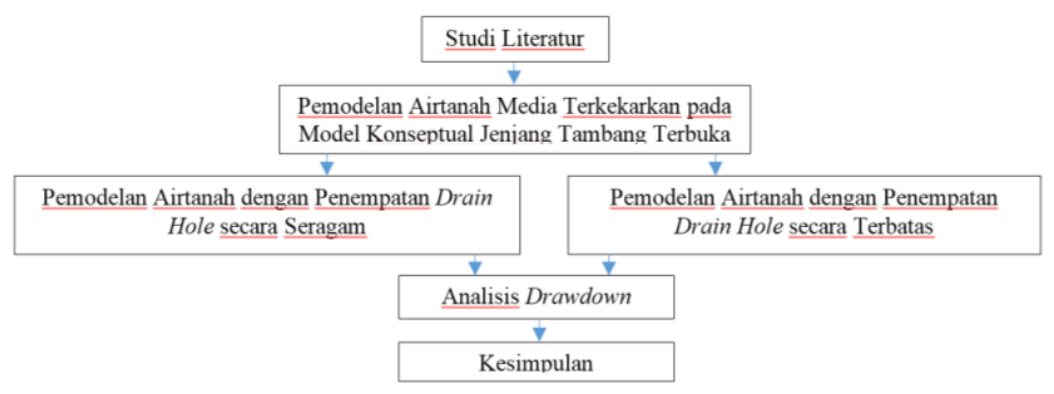

Gambar 1. Diagram Alir Penyelesaian Masalah 


\section{PEMODELAN ALIRAN AIRTANAH}

Simulator Visual Modflow memecahkan persamaan 3-D yang mengatur persamaan diferensial parsial-untuk kondisi transient, dengan aliran airtanah jenuh melalui media berpori untuk menghasilkan distribusi spasial head potensiometri sebagai fungsi waktu.

$\frac{\partial}{\partial x}\left(K x x \frac{\partial h}{\partial x}\right)+\frac{\partial}{\partial y}\left(K y y \frac{\partial h}{\partial x}\right)+\frac{\partial}{\partial z}\left(K z z \frac{\partial h}{\partial z}\right)-q s=S s \frac{\partial h}{\partial t}$

Dimana $K x x, \quad K y y$ and $K z z$ adalah nilai-nilai konduktivitas hidraulik [L/T] sepanjang koordinat sumbu $x, y$, dan $z$, yang diasumsikan sejajar dengan sumbu utama konduktivitas hidraulik, $h$ adalah head [L]; qs adalah fluks volumetrik per satuan volume akuifer dan merupakan fungsi dari sumur dewatering; Ss adalah koefisien penyimpanan akuifer [1/L], dan $t$ adalah waktu (T).

Model batuan terkekarkan dalam karakteristik hidrogeologi dibagi menjadi 3 bagian yaitu Equivalent Porous Medium Model, Double Porosity Model, dan Discrete Fracture Model (Singhal dan Gupta, 1999). Untuk melakukan pemodelan aliran airtanah dalam media terkekarkan menggunakan konsep gabungan, yaitu media porous dan media terkekarkan. Setiap grid yang ada di dalam model sedemikian mungkin merepresentasikan kondisi kekar yang ada di lapangan. Konsep ini telah dicoba oleh Yang dkk., 2009 yang menggambarkan media terkekarkan misalnya berupa fault dapat diproyeksikan ke dalam satuan grid. Gambar 2a merepresentasikan suatu fault yang akan dijadikan contoh grid dalam Representation of Elementary Volume (REV).
Gambar 2b menjelaskan media terkekarkan yang diimplementasikan dalam REV dan Gambar 2c menjelaskan model struktur yang digambarkan dalam media berpori (porous media).

Leech dkk., 2007 melakukan penelitian di Tambang Terbuka Batu Hijau dengan menggunakan horisontal drain hole untuk menurunkan muka airtanah yang ada di sekitar lereng dalam rangka menjaga kondisi lereng tetap aman. Pemasangan drain hole yang tepat akan menghasilkan penurunan muka airtanah yang optimal. Kondisi hidrostratigrafi yang komplek memberikan pengaruh dalam penempatan horizontal drain hole. Produktivitas drain hole yang dipasang di lapangan dapat dipantau melalui sumur piezometer yang dipasang mendekati screen dari drain hole tersebut.

Kegiatan horisontal dewatering dengan drain hole harus memiliki tujuan dan target yang jelas. Desain dari penempatan drain hole dapat dioptimalkan dengan jalan melakukan simulasi dengan simulator. Media aliran yang berbeda menyebabkan panjang pipa drain hole yang dipasang akan memiliki dimensi yang beragam terkait panjang, diameter, lokasi dan arah penempatan. Gambar 3a menjelaskan fungsi perbedaan panjang pipa drain hole pada media yang berbeda (Read dan Stacy., 2009). Gambar $3 \mathrm{~b}$ menjelaskan kegiatan pemboran horisontal drain hole pada media terkekarkan, sedangkan Gambar 3c menjelaskan mengenai keluarnya air dari lubang drain hole yang belum optimal akibat pemasangan yang seragam (Leech dkk., 2007).
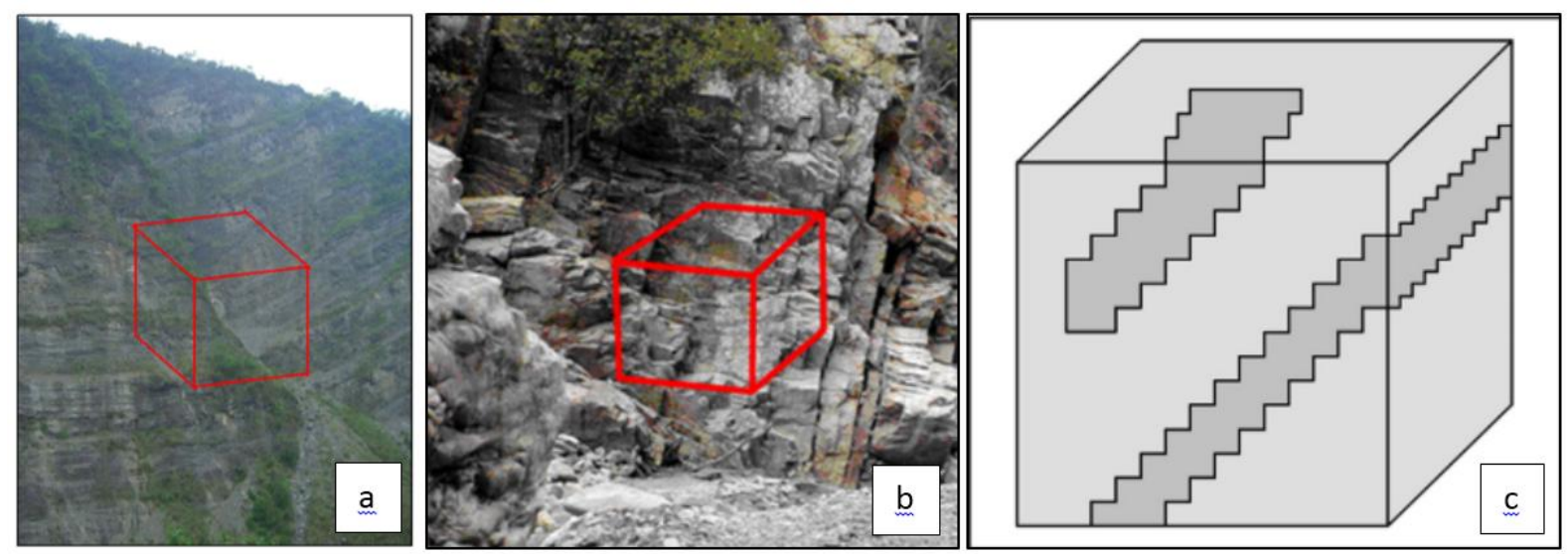

Gambar 2. Penerapan Media Terkekarkan pada Media Berpori (dikutip dari Yang dkk., 2009) 


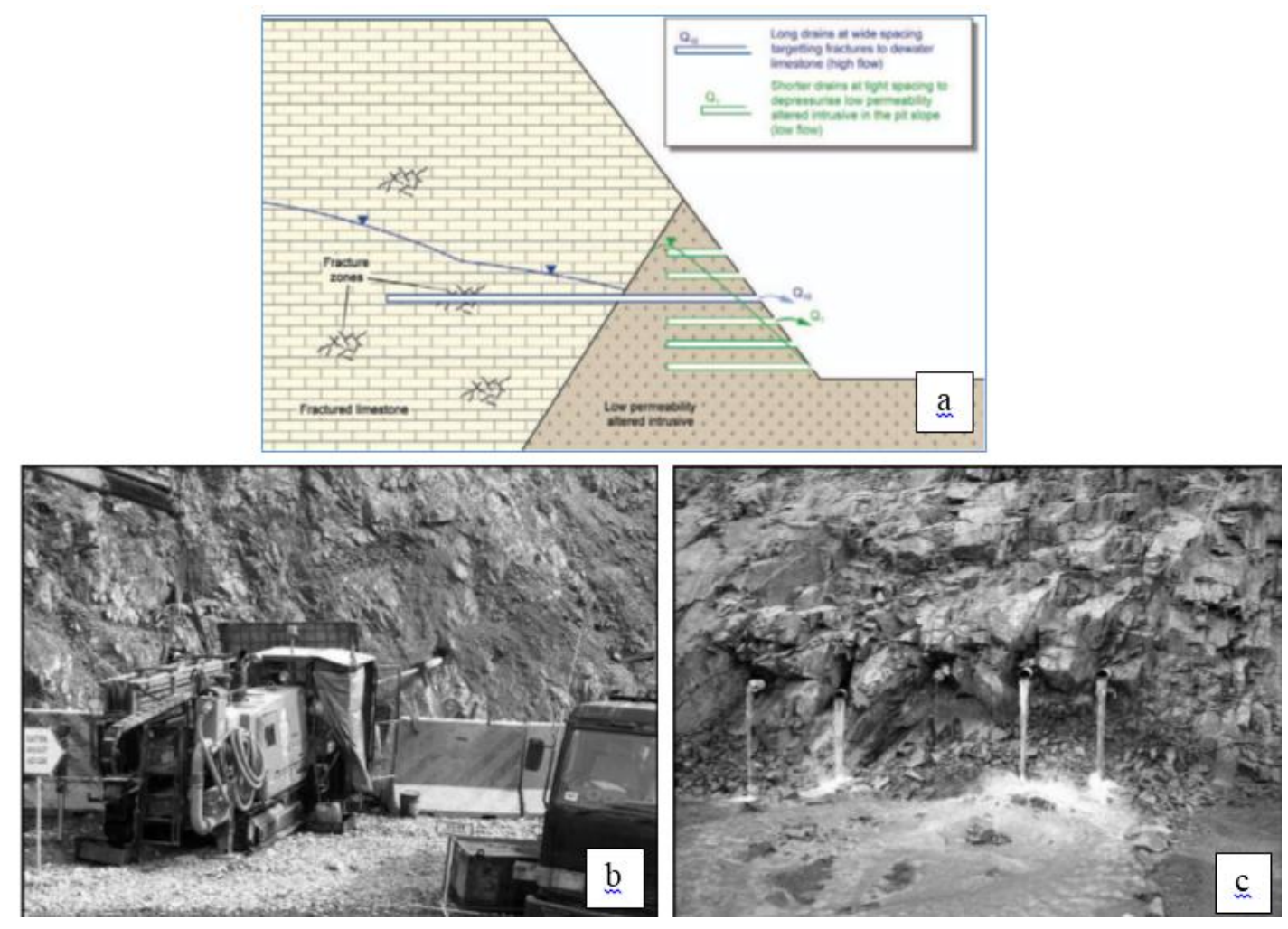

Gambar 3. Penempatan Horisontal Drain hole di Lereng Tambang Terbuka (dikutip dari Read dan Stacy., 2009 serta Leech dkk., 2007)

\section{HASIL DAN PEMBAHASAN (RESULT AND DISCUSIONS)}

Dalam membuat model konseptual ini dilakukan deskripsi boundary condition untuk membatasi parameter apa saja yang akan dipakai dalam kegiatan pemodelan aliran airtanah (Tabel 1). Asumsi dan pembatasan yang digunakan adalah sebagai berikut:

1. Contoh kasus adalah model jenjang penambangan pada batuan gamping terkekarkan,

2. Setiap grid di dalam model merepresentasikan kondisi media yang terkekarkan dan heterogen,

3. Setiap grid memiliki dimensi cell $1 \mathrm{~m} \mathrm{x} 1 \mathrm{~m}$ $\mathrm{x} 1 \mathrm{~m}$,

4. Nilai distribusi sebaran parameter konduktivitas hidraulik, storativitas, porositas batuan, recharge, evapotranspirasi diasumsikan mengikuti Antoro dkk., 2011, Cahyadi dkk., 2015,

5. Drain hole dalam simulator diasumsikan sebagai bidang drain dengan nilai konduktan tertentu.
Penyelesaian metode numeriknya menggunakan metode finite difference (FDM) menggunakan Visual Modlfow 2.8.1.

Model konseptual secara 3D dapat dilihat pada Gambar 4. Gambar 4a menunjukkan boundary model pada saat sebelum dilakukan kegiatan penambangan. Identitas warna biru, hijau, putih, dan merah menunjukkan distribusi sebaran distribusi konduktivitas hidraulik batugamping yang menyerupai kantung - kantung air pada kondisi sebaran RQD yang berbeda. Gambar 4b menunjukkan kondisi topografi yang telah mengalami perubahan akibat penambangan. Penambangan tersebut memiliki geometri tinggi jenjang $10 \mathrm{~m}$ dengan sudut kemiringan jenjang $40^{\circ}$. Gambar $4 \mathrm{c}$ menunjukkan hasil penyelesaian aliran airtanah dengan finite diference method yang mengalir dari arah timur menuju ke barat. Gambar 4d menunjukkan terpotongnya head airtanah pada bagian barat akibat kegiatan penambangan yang menimbulkan munculnya rembesan airtanah (seepage) di sepanjang lereng. Kondisi ini kalau tidak ditangani secara cepat dapat membuat kestabilan lereng menjadi terganggu. Kegiatan penirisan yang dilakukan adalah dengan melakukan instalasi drain hole 
dengan 2 skema. Simulasi dilakukan dengan memasang drain hole pada bagian dasar jenjang (toe) di sepanjang lereng secara seragam dan atau terbatas pada nilai permeabilitas yang besar. Spesifikasi drain hole tersebut terdiri dari panjang $100 \mathrm{~m}$, diameter $0,1 \mathrm{~m}$. Pemasangan drain hole dengan 2 skema yang berbeda akan memberikan pengertian pentingnya pemasangan drain hole pada sasaran yang tepat yaitu pada lokasi yang memiliki nilai permeabilitas yang besar. Sedikit jumlah drain hole yang dipasang pada lokasi yang tepat sesuai dengan model konseptual akan lebih efektif dibandingkan yang seragam (Rahardjo dkk., 2003).

Tabel 1. Parameter dalam Pemodelan Konseptual Aliran Airtanah pada Jenjang Penambangan

\begin{tabular}{|l|l|}
\hline \multicolumn{1}{|c|}{ Parameter } & \multicolumn{1}{c|}{ Keterangan } \\
\hline Konduktivitas Hidraulik RQD $>75 \%$ & $10^{-9} \mathrm{~m} / \mathrm{s}$ \\
\hline Konduktivitas Hidraulik RQD 50-75\% & $10^{-8} \mathrm{~m} / \mathrm{s}$ \\
\hline Konduktivitas Hidraulik RQD 25-50\% & $10^{-7} \mathrm{~m} / \mathrm{s}$ \\
\hline Konduktivitas Hidraulik RQD $<25 \%$ & $10^{-6} \mathrm{~m} / \mathrm{s}$ \\
\hline Konduktivitas Hidraulik Fault & $10^{-5} \mathrm{~m} / \mathrm{s}$ \\
\hline Ss & 0,01 \\
\hline Sy & 0,2 \\
\hline Curah Hujan & $4000 \mathrm{~mm} / \mathrm{th}$ \\
\hline Recharge 15\% dari Curah Hujan & $600 \mathrm{~mm} / \mathrm{th}$ \\
\hline Evapotranspirasi 5\% dari Curah Hujan & $200 \mathrm{~mm} /$ th \\
\hline Initial head & Model bagian barat memiliki initial head $148 \mathrm{~m}$ \\
& Model bagian timur memiliki initial head $143 \mathrm{~m}$ \\
\hline Waktu Simulasi (t) & 360 hari \\
\hline Drain Conductance & $0,8 \mathrm{~m} /$ hari \\
\hline Sumur Pantau & 7 buah, untuk memantau fluktuasi airtanah \\
\hline
\end{tabular}
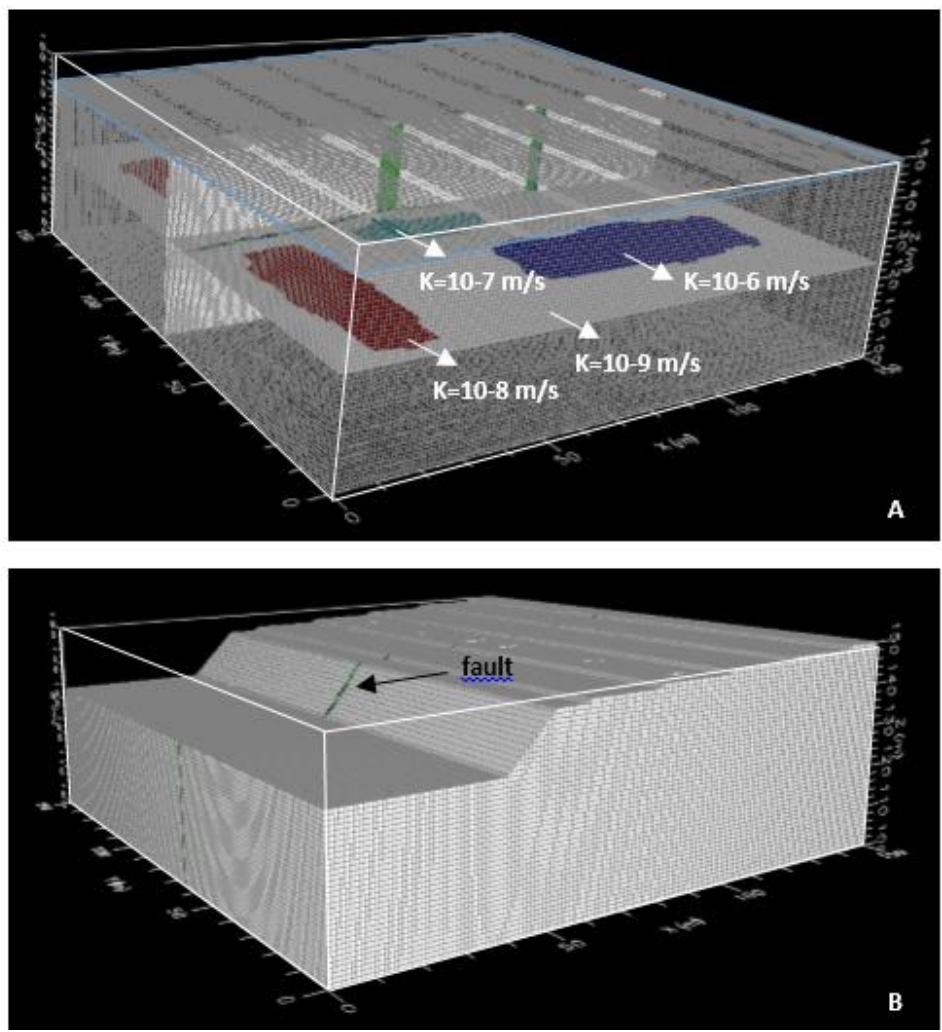

Gambar 4. Konseptual Model Distribusi Sebaran Permeabilitas dan Jenjang Penambangan 

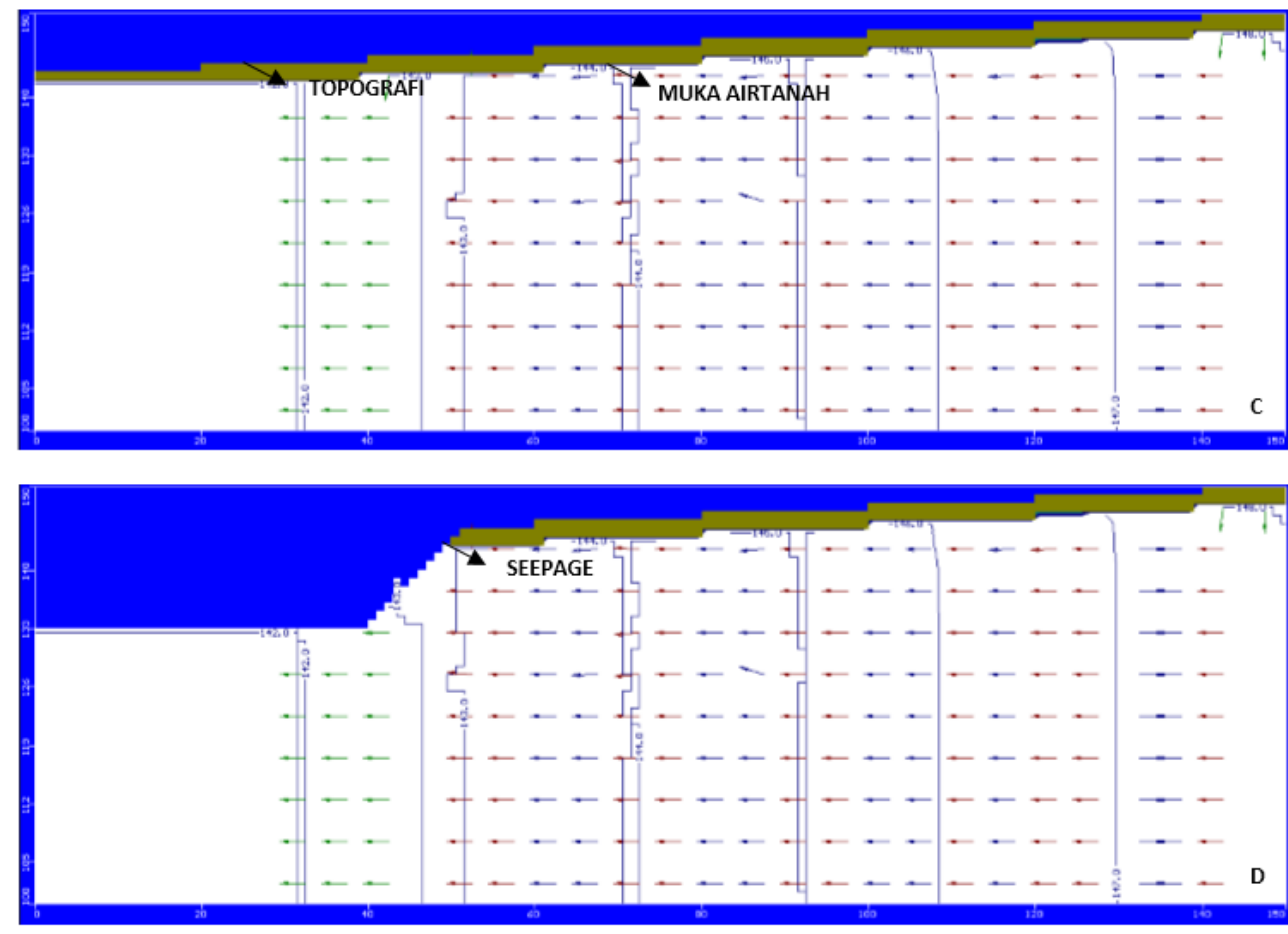

Lanjutan Gambar 4. Konseptual Model Distribusi Head Sebelum dan Sesudah Ditambang

\section{PENEMPATAN LUBANG DRAIN HOLE SECARA SERAGAM}

Pada skema yang pertama ini diasumsikan minimnya informasi mengenai sebaran distribusi konduktivitas hidraulik, maka pemasangan drain hole dilakukan secara seragam di lapangan. Drain hole dengan panjang $100 \mathrm{~m}$ dan diameter $0,1 \mathrm{~m}$ dipasang di sepanjang lereng dengan spasi $20 \mathrm{~m}$. Cara ini di lapangan menghasilkan jumlah lubang drain hole yang banyak. Pada model konseptual ini dihasilkan sebanyak 7 lubang drain hole. Gambar 5a menunjukkan penampang jenjang yang memperlihatkan drain hole dipasang tegak lurus dengan bagian dasar jenjang (toe). Gambar 5b menunjukkan instalasi drain hole spasi $20 \mathrm{~m}$ yang menembus berbagai permeabiltas batuan. Gambar 5c menunjukkan distribusi persebaran head akibat instalasi sebanyak 7 drain hole setelah model dijalankan selama $\mathrm{t}=360$ hari. Gambar 5d menunjukkan distribusi penurunan muka airtanah akibat instalasi drain hole setelah $\mathrm{t}=360$ hari. Dari gambar tersebut tampak jelas bahwa pengaruh permeabilitas terhadap distribusi head dan drawdown.

\section{PENEMPATAN LUBANG DRAIN HOLE TERBATAS}

Skema yang kedua diasumsikan kondisi persebaran konduktivitas hidraulik telah diketahui dengan metode tertentu misalnya geostatistik (Cahyadi dkk., 2014), artificial neural network (Cahyadi dkk 2015). Instalasi drain hole hanya difokuskan pada batuan dengan nilai permeabilitas yang besar, dengan panjang lubang drain hole maksimal $100 \mathrm{~m}$ dan kurang dari $100 \mathrm{~m}$ menyesuaikan dengan target permeabilitas. Implementasi cara ini apabila diterapkan di lapangan akan menurunkan biaya operasional penirisan tambang, karena dapat mereduksi jumlah dan panjang lubang bor. Gambar 6a menunjukkan penampang jenjang yang memperlihatkan drain hole dipasang tegak lurus dengan bagian toe jenjang. Gambar $6 \mathrm{~b}$ menunjukkan instalasi drain hole pada permeabilitas batuan yang besar dengan panjang bervariasi maksimal $100 \mathrm{~m}$. Gambar 6c menunjukkan distribusi sebaran head setelah $\mathrm{t}=360$ hari. Gambar $6 \mathrm{~d}$ menunjukkan distribusi sebaran drawdown akibat instalasi pada permeabilitas batuan besar setelah $\mathrm{t}=360$ hari. 

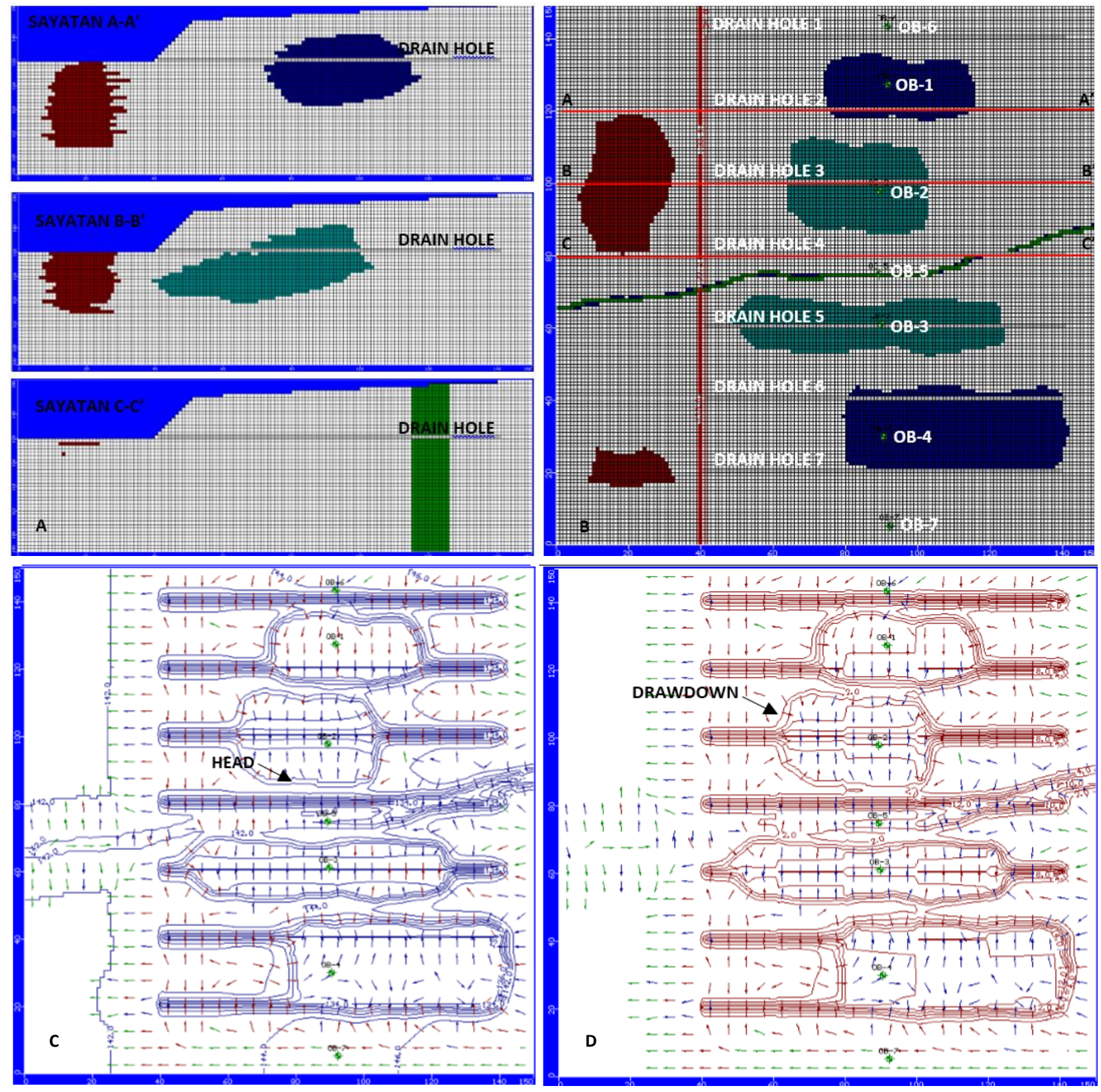

Gambar 5. Penempatan Drain Hole Secara Seragam dan Pengaruhnya 

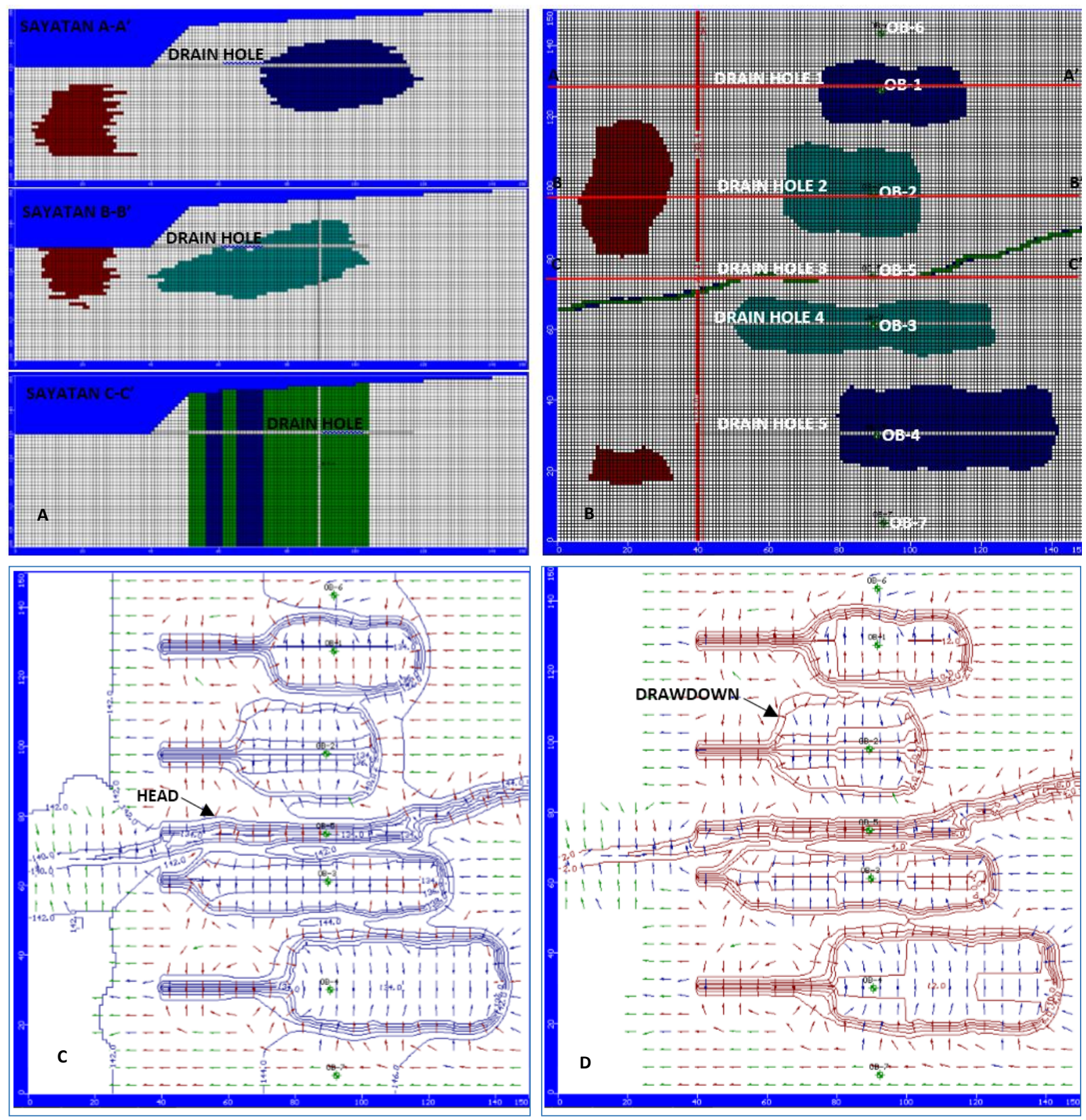

Gambar 6. Penempatan Drain Hole Secara Terbatas dan Pengaruhnya 


\section{ANALISIS HASIL DRAWDOWN}

Percobaan simulasi ini menempatkan 7 piezometer yang dipasang pada lokasi permeabilitas batuan yang berbeda, tujuannya untuk mengetahui pengaruh fluktuasi airtanah dari waktu ke waktu akibat instalasi drain hole dengan menggunakan 2 skema. Pada skema pertama, drain hole 1 dipasang pada populasi permeablitas batuan $10^{-9} \mathrm{~m} / \mathrm{s}$, drawdown yang dihasilkan piezometer OB-6 pada saat $\mathrm{t}=360$ hari adalah $0 \mathrm{~m}$. Drain hole 2 dipasang pada permeabilitas batuan $10^{-6} \mathrm{~m} / \mathrm{s}$, drawdown yang dihasilkan piezometer $\mathrm{OB}-1$ pada saat $\mathrm{t}=360$ hari adalah 8,61 m. Drain hole 3 dipasang pada populasi permeabilitas batuan $10^{-7} \mathrm{~m} / \mathrm{s}$, drawdown yang dihasilkan OB-2 pada saat $\mathrm{t}=360$ hari adalah $1,7 \mathrm{~m}$. Drain hole 4 dipasang pada populasi permeabilitas batuan $10^{-9} \mathrm{~m} / \mathrm{s}$ dan menembus fault dengan permeabilitas $10^{-5} \mathrm{~m} / \mathrm{s}$. Pengamatan drawdown pada OB-5 menunjukkan penurunan airtanah sebesar $4,4 \mathrm{~m}$ setelah $\mathrm{t}=360$ hari. Drain hole 5 dipasang pada populasi permeabilitas batuan $10^{-7} \mathrm{~m} / \mathrm{s}$, drawdown yang dihasilkan piezometer OB-3 setelah $\mathrm{t}=360$ hari adalah $0,33 \mathrm{~m}$. Drain hole 6 dipasang pada populasi permeabilitas batuan $10^{-6} \mathrm{~m} / \mathrm{s}$, drawdown yang dihasilkan dari pengamatan OB4 setelah t=360 hari adalah 6,99 m. Drain hole 7 dipasang pada populasi permeabilitas batuan $10^{-9}$ $\mathrm{m} / \mathrm{s}$, dengan penurunan drawdown pada OB-7 sebesar $0 \mathrm{~m}$.
Dari percobaan skema 1 didapatkan hasil bahwa populasi batuan yang memiliki nilai permeabilitas $10^{-9} \mathrm{~m} / \mathrm{s}$ tidak dapat mengalirkan airtanah sehingga fluktuasi airtanah yang ada di piezometer tetap atau tidak terjadi penurunan muka airtanah.

Skema kedua drain hole dipasang pada populasi batuan dengan permeabiltas besar. Drain hole 1 dipasang pada populasi batuan $10^{-6} \mathrm{~m} / \mathrm{s}$, dengan drawdown yang terpantau di OB-1 sebesar 8,9 m. Drain hole 2 dipasang pada populasi permeabilitas batuan $10^{-7} \mathrm{~m} / \mathrm{s}$, dengan drawdown yang terpantau di OB-2 sebesar 1,7 m. Drain hole 3 dipasang di sepanjang fault dengan permebilitas batuan $10^{-5} \mathrm{~m} / \mathrm{s}$, drawdown yang dihasilkan pada OB-5 adalah 7,26 m. Drain hole 4 dipasang pada permeabilitas batuan $10^{-7} \mathrm{~m} / \mathrm{s}$, dengan drawdown pada OB-3 sebesar $0,66 \mathrm{~m}$. Drain hole 5 dipasang pada permeabilitas $10^{-6} \mathrm{~m} / \mathrm{s}$, dengan drawdown yang dihasilkan pada OB-4 sebesar 6,61 m. Dari percobaan ini diperoleh hasil dengan intalasi drain hole dengan jumlah dan panjang terbatas didapatkan penurunan muka airtanah yang hasilnya hampir sama dengan skema pertama. Cara ini dapat menghemat biaya operasional penirisan tambang yang ada di lapangan, serta menghindari tidak berfungsinya drain hole di lapangan. Dengan demikian pemasangan drain hole dalam jumlah dan panjang terbatas dapat diimplementasikan di lapangan berdasarkan contoh kasus model konseptual ini.

Tabel 2. Penurunan Muka Airtanah di Lokasi Piezometer

\begin{tabular}{|c|c|c|c|c|c|c|c|c|c|c|c|c|c|c|}
\hline \multirow[b]{2}{*}{ Time } & \multicolumn{14}{|c|}{ SUMUR PANTAU (m) } \\
\hline & $\begin{array}{l}\text { OB- } \\
1 / A\end{array}$ & $\begin{array}{l}\text { OB- } \\
1 / B\end{array}$ & $\begin{array}{l}O B- \\
2 / A\end{array}$ & $\begin{array}{l}\text { OB- } \\
2 / B\end{array}$ & $\begin{array}{l}\text { OB- } \\
3 / A\end{array}$ & $\begin{array}{l}\text { OB- } \\
3 / B\end{array}$ & $\begin{array}{l}\text { OB- } \\
4 / A\end{array}$ & $\begin{array}{l}\text { OB- } \\
4 / B\end{array}$ & $\begin{array}{l}\text { OB- } \\
5 / A\end{array}$ & $\begin{array}{l}\text { OB- } \\
5 / B\end{array}$ & $\begin{array}{l}\text { OB- } \\
6 / A\end{array}$ & $\begin{array}{l}\text { OB- } \\
6 / B\end{array}$ & $\begin{array}{l}\text { OB- } \\
7 / A\end{array}$ & $\begin{array}{l}\text { OB- } \\
7 / B\end{array}$ \\
\hline 36 & 1,02 & 1,18 & 0,14 & 0,14 & 0,01 & 0,01 & 0,16 & 0,15 & 1,34 & 3,60 & 0,00 & 0,00 & 0,00 & 0,00 \\
\hline 72 & 2,54 & 2,86 & 0,30 & 0,30 & 0,03 & 0,03 & 0,91 & 0,86 & 2,08 & 0,47 & 0,00 & 0,00 & 0,00 & 0,00 \\
\hline 108 & 4,00 & 4,43 & 0,46 & 0,46 & 0,06 & 0,06 & 1,89 & 1,83 & 2,60 & 5,40 & 0,00 & 0,00 & 0,00 & 0,00 \\
\hline 144 & 5,20 & 5,65 & 0,63 & 0,63 & 0,11 & 0,11 & 2,90 & 2,77 & 3,00 & 5,58 & 0,00 & 0,00 & 0,00 & 0,00 \\
\hline 180 & 6,15 & 6,20 & 0,80 & 0,80 & 0,18 & 0,18 & 3,84 & 3,23 & 3,33 & 5,99 & 0,00 & 0,00 & 0,00 & 0,00 \\
\hline 216 & 6,88 & 6,94 & 0,98 & 0,98 & 0,25 & 0,25 & 4,66 & 3,94 & 3,60 & 6,23 & 0,00 & 0,00 & 0,00 & 0,00 \\
\hline 252 & 7,46 & 7,63 & 1,16 & 1,16 & 0,34 & 0,34 & 5,38 & 4,77 & 3,84 & 6,58 & 0,00 & 0,00 & 0,00 & 0,00 \\
\hline 288 & 7,92 & 8,17 & 1,35 & 1,35 & 0,44 & 0,44 & 6,00 & 5,48 & 4,04 & 6,84 & 0,00 & 0,00 & 0,00 & 0,00 \\
\hline 324 & 8,30 & 8,58 & 1,53 & 1,52 & 0,55 & 0,55 & 6,53 & 6,09 & 4,23 & 7,07 & 0,01 & 0,01 & 0,00 & 0,00 \\
\hline 360 & 8,61 & 8,91 & 1,70 & 1,70 & 0,66 & 0,66 & 6,99 & 6,61 & 4,40 & 7,26 & 0,01 & 0,01 & 0,00 & 0,00 \\
\hline
\end{tabular}

Keterangan : Kode A = Skema 1, Kode B = Skema 2. 


\section{KESIMPULAN (CONCLUSION)}

Dari percobaan 2 skema simulasi penempatan drain hole dalam penirisan tambang terbuka didapatkan hasil sebagai berikut :

1. Penempatan drain hole skema 1 dengan jumlah 7 lubang drain hole, spasi $20 \mathrm{~m}$, panjang lubang bor $100 \mathrm{~m}$, dan skema 2 menempatkan 5 lubang drain hole dengan penempatan terbatas, panjang lubang bor maksimal $100 \mathrm{~m}$, menghasilkan fluktuasi penurunan muka airtanah yang mirip pada $\mathrm{t}=360 \mathrm{~m}$.

2. Skema 2 lebih menguntungkan dibandingkan skema 1 karena rendahnya biaya operasional penirisan tambang yang dikeluarkan.

3. Penurunan muka airtanah sangat sensitive terhadap distribusi nilai populasi permeabilitas batuan dengan nilai $>10^{-6} \mathrm{~m} / \mathrm{s}$.

4. Pemilihan skema penempatan drain hole terbatas di lapangan sangat penting untuk mengoptimalkan peran drain hole dengan cara memaksimalkan informasi distribusi sebaran konduktivitas hidraulik.

\section{UCAPAN TERIMAKASIH (ACKNOWLEDGEMENT)}

Penulis mengucapkan terimakasih kepada Dr. S. Koesnaryo yang telah memberikan ijin atas penggunaan Software Visual MODFLOW 2.8.1 lisensi Magister Teknik Pertambangan UPN "Veteran" Yogyakarta. Selain itu penulis mengucapkan terimakasih kepada Irwan Iskandar Ph.D sebagai mitra diskusi di Laboratorium Hidrogeologi Tambang ITB.

\section{DAFTAR PUSTAKA (REFERENCES)}

Antoro, B., Margotomo, W., Perdana, A., Widijanto, E., Wiwoho. N., Ginting, A.P., Santosa, R.G.I., Pramuji, Silaen, H., Setyadi, H., Iribaram, F., Mundu, S., Garjito, W., Sumarwan, F., Rohmadi, A., Setiadi, T., Afwan, A., Asrizal., Pahala, A.R., Prasetyo, N., 2011. Geologi dan geoteknik tambang terbuka grasberg PTFI, Aksara Buana.

Cahyadi T.A., Widodo L.E., Iskandar I., Sukaerang, Suyono., 2015. Modeling spatial distribution of 3D isotropic hydraulic conductivity based on hcsystem for fractured groundwater flow media using neural network case study grasberg open pit of PTFI and surrounding., International Symposium on Earth Science and Technology, Japan, 59-64.

Cahyadi, T.A., Notosiswoyo, S., Widodo, L.E., Iskandar, I., and Suyono., 2014. Distribusi sebaran konduktivitas hidraulik dari hasil uji akuifer - constant head permeabilitas pada batuan sedimen secara heterogen, Proceeding TPT Perhapi XXIII, 352-360.

Leech S., McGann, 2007. Open pit slope depressurization using horizontal drains - a Case Study Newmont, https://www.imwa.info/docs/imwa_2008/ IMWA2008_035_Leech.pdf. Diunduh pada tanggal 16 Juli 2014.

McDonald M.G., Harbaugh A.W., 1988. A Modular three-dimensional finite difference groundwater flow model, Techniques of Water Resources Investigations Book 6. U.S. Geological Survey, Washington, D.C.

Rahardjo, H., Hritzuk, K. J., Leong, E. C. \& Rezaur, R. B., 2003. Effectiveness of horizontal drains for slope stability. Engineering Geology, 69, 295-308

Read J., Stacey P., 2009. Guidelines for Open Pit Slope Design, CRC Pres, Balkema, Natherland.

Silaen H., Pramuji, Ginting A., Widyanto D., Waromi I., 2011. Hydrogeological and pore water pressure characterization at south west sector of Grasberg open pit, Papua, Proceedings JCM Makassar The $36 \mathrm{t}^{\mathrm{h}}$ HAGI and $40^{\text {th }}$ IAGI Annual Convention and Exhibition.

Singhal B.B.S., Gupta, R.P., 1999. Applied hydrogeology of fractured rocks, Kluwer Academic Publishers, The Netherlands.

Yang F.R., Lee C. H., Kung W.J., Yeh H.F., 2009. The impact of tunneling construction on the hydrogeological environment of "Tseng-Wen Reservoir Transbasin Diversion Project" in Taiwan, Engineering Geology 103, 39-58. 